University of Wollongong

Research Online

Australian Institute for Innovative Materials -

Papers

Australian Institute for Innovative Materials

2014

Enhanced visible-light photocatalytic activity of g-C3N4/TiO2 films

\author{
Natkritta Boonprakob \\ Chiang Mai University \\ Natda Wetchakun \\ Chiang Mai University \\ Sukon Phanichphant \\ Chiang Mai University \\ David Wexler \\ University of Wollongong, davidw@uow.edu.au \\ Peter Sherrell \\ University of Wollongong, psherrel@uow.edu.au
}

See next page for additional authors

Follow this and additional works at: https://ro.uow.edu.au/aiimpapers

Part of the Engineering Commons, and the Physical Sciences and Mathematics Commons

Research Online is the open access institutional repository for the University of Wollongong. For further information contact the UOW Library: research-pubs@uow.edu.au 


\title{
Enhanced visible-light photocatalytic activity of g-C3N4/TiO2 films
}

\begin{abstract}
Enhanced photocatalytic degradation of methylene blue (MB) using graphitic carbon nitride/titanium dioxide (g-C3N4/TiO2) catalyst films has been demonstrated in this present work. The g-C3N4/TiO2 composites were prepared by directly heating the mixture of melamine and pre-synthesized TiO2 nanoparticles in Ar gas flow. The g-C3N4 contents in the g-C3N4/TiO2 composites were varied as 0, 20, 50 and $70 \mathrm{wt} \%$. It was found that the visible-light-induced photocatalytic degradation of MB was remarkably increased upon coupling TiO2 with g-C3N4 and the best degradation performance of $\sim 70 \%$ was obtained from $50 \mathrm{wt} \% \mathrm{~g}-\mathrm{C} 3 \mathrm{~N} 4$ loading content. Results from UV-vis absorption study, Electron microscopy, Fourier transform infrared spectroscopy and X-ray photoelectron spectroscopy suggest that the improved photoactivity is due to a decrease in band gap energy, an increased light absorption in visible light region and possibly an enhanced electron-hole separation efficiency as a result of effective interfacial electron transfer between TiO2 and g-C3N4 of the g-C3N4/TiO2 composite film. Based on the obtained results, the possible MB degradation mechanism is ascribed mainly to the generation of active species induced by the photogenerated electrons.
\end{abstract}

\section{Keywords}

tio2, c3n4, g, films, activity, enhanced, photocatalytic, light, visible

Disciplines

Engineering | Physical Sciences and Mathematics

\section{Publication Details}

Boonprakob, N., Wetchakun, N., Phanichphant, S., Waxler, D., Sherrell, P., Nattestad, A., Chen, J. \& Inceesungvorn, B. (2014). Enhanced visible-light photocatalytic activity of g-C3N4/TiO2 films. Journal of Colloid and Interface Science, 417 402-409.

\section{Authors}

Natkritta Boonprakob, Natda Wetchakun, Sukon Phanichphant, David Wexler, Peter Sherrell, Andrew Nattestad, Jun Chen, and Burapat Inceesungvorn 


\section{Enhanced visible-light photocatalytic activity of $\mathrm{g}-\mathrm{C}_{3} \mathrm{~N}_{4} / \mathrm{TiO}_{2}$}

\section{films}

Natkritta Boonprakob ${ }^{\mathrm{a}}$, Natda Wetchakun ${ }^{\mathrm{b}}$, Sukon Phanichphant ${ }^{\mathrm{c}}$, David Waxler ${ }^{\mathrm{d}}$

Peter Sherrell $^{\mathrm{e}}$, Andrew Nattestad ${ }^{\mathrm{e}}$, Jun Chen ${ }^{\mathrm{e}}$, Burapat Inceesungvorn , $^{\text {** }}$

${ }^{a}$ Nanoscience and Nanotechnology Program, Graduated School, Chiang Mai University, Chiang Mai 50200, Thailand.

${ }^{b}$ Department of Physics and Materials Science, Faculty of Science, Chiang Mai University, Chiang Mai 50200, Thailand.

${ }^{c}$ Materials Science Research Centre, Faculty of Science, Chiang Mai University, Chiang Mai 50200, Thailand.

${ }^{d}$ Department of Mechanical, Material and Mechatronic, Faculty of Engineering, University of Wollongong, NSW 2522 Australia.

${ }^{e}$ Intelligent Polymer Research Institute, ARC Centre of Excellent for Electromaterials Science, Australian Institute of Innovative Materials, University of Wollongong, NSW 2522 Australia.

${ }^{f}$ Department of Chemistry, Faculty of Science, Chiang Mai University, Chiang Mai 50200, Thailand.

\section{Corresponding Author}

*Email address: binceesungvorn@gmail.com, Phone: +66 81 0255659, Fax: +66 53892277 


\section{ABSTRACT}

Enhanced photocatalytic degradation of methylene blue (MB) using graphitic carbon nitride/titanium dioxide $\left(\mathrm{g}-\mathrm{C}_{3} \mathrm{~N}_{4} / \mathrm{TiO}_{2}\right.$ ) catalyst films has been demonstrated in this present work. The $\mathrm{g}-\mathrm{C}_{3} \mathrm{~N}_{4} / \mathrm{TiO}_{2}$ composites were prepared by directly heating the mixture of melamine and presynthesized $\mathrm{TiO}_{2}$ nanoparticles in $\mathrm{Ar}$ gas flow. The $\mathrm{g}-\mathrm{C}_{3} \mathrm{~N}_{4}$ contents in the $\mathrm{g}-\mathrm{C}_{3} \mathrm{~N}_{4} / \mathrm{TiO} 2$ composites were varied as $0,20,50$ and $70 \mathrm{wt} \%$. It was found that the visible-light-induced photocatalytic degradation of $\mathrm{MB}$ was remarkably increased upon coupling $\mathrm{TiO}_{2}$ with $\mathrm{g}-\mathrm{C}_{3} \mathrm{~N}_{4}$ and the best degradation performance of $\sim 70 \%$ was obtained from $50 \mathrm{wt} \% \mathrm{~g}-\mathrm{C}_{3} \mathrm{~N}_{4}$ loading content. Results from UV-vis absorption study, Electron microscopy, Fourier transform infrared spectroscopy and X-ray photoelectron spectroscopy suggest that the improved photoactivity is due to a decrease of band gap energy, an increased light absorption in visible light region and possibly an enhanced electron-hole separation efficiency as a result of effective interfacial electron transfer between $\mathrm{TiO}_{2}$ and $\mathrm{g}-\mathrm{C}_{3} \mathrm{~N}_{4}$ of the $\mathrm{g}-\mathrm{C}_{3} \mathrm{~N}_{4} / \mathrm{TiO}_{2}$ composite film. Based on the obtained results, the possible MB degradation mechanism is ascribed mainly to the generation of active species induced by the photogenerated electrons.

Keywords: Titanium dioxide; Graphitic carbon nitride; Photocatalysis; Visible light

\section{Introduction}

Over the last few decades, the semiconductor-based photocatalysis has emerged as an alternative and environmentally benign wastewater treatment technology due to its destructive ability towards a wide range of inorganic and organic pollutants. To date, a large number of semiconductors such as $\mathrm{ZnO}, \mathrm{CdS}, \mathrm{V}_{2} \mathrm{O}_{5}, \mathrm{WO}_{3}$, and $\mathrm{TiO}_{2}$ have found to be active photocatalysts for photodegradation of various organic contaminants [1-5]. Among them, $\mathrm{TiO}_{2}$ has been one of the promising 
photocatalysts due to its low cost, nontoxicity and long-term stability [6-8]. However, its large band gap energy of $\sim 3.2 \mathrm{eV}$ and the high recombination rate of electron-hole pairs in excited $\mathrm{TiO}_{2}$ have hindered its practical application $[9,10]$. Therefore, much effort has been devoted to extend the light absorption of $\mathrm{TiO}_{2}$ into visible light region as well as to reduce the photogenerated charge recombination. Various strategies have been proposed to obtain the $\mathrm{TiO}_{2}$ with such properties including doping with metallic and/or non-metallic elements [11-14] and forming heterojunctions with other narrow band gap semiconductors $[15,16]$.

Coupling $\mathrm{TiO}_{2}$ with visible light-sensitized semiconductors has shown to be beneficial to the improvement of photocatalytic performance due to the synergistic effect such as enhanced light harvesting, improved photostability and efficient photoexcited charge separation [17]. To achieve such desired coupling effect, close interfacial connection between the two semiconductors with appropriate conduction and valence band levels is necessary, so that spatially smooth charge transfer via heterojunction can proceed [18].

Recently, the metal-free graphic carbon nitride $\left(\mathrm{g}-\mathrm{C}_{3} \mathrm{~N}_{4}\right)$ has attracted considerable attention as a potential visible light photocatalyst due to its high thermal and chemical stabilities together with its moderate band gap energy of $\sim 2.7-2.8 \mathrm{eV}$ depending on the degree of thermal condensation $[19,20]$. The delocalized conjugated $\pi$ structure of $\mathrm{g}_{-} \mathrm{C}_{3} \mathrm{~N}_{4}$ also offers a relatively slow charge recombination and a rapid photoinduced charge separation in the electron transfer process [21], thus making this material a sensitizer candidate for the design of efficient visible-light-driven photocatalyst. Therefore, coupling $\mathrm{g}-\mathrm{C}_{3} \mathrm{~N}_{4}$ with $\mathrm{TiO}_{2}$ may be a suitable approach to achieve the improved charge separation and the enhanced light harvesting ability of the $\mathrm{TiO}_{2}$ semiconductor. The application of $\mathrm{g}-\mathrm{C}_{3} \mathrm{~N}_{4}$ as a sensitizer in a composite photocatalyst has previously been 
investigated. For example, Wang et al. [21] prepared $\mathrm{g}-\mathrm{C}_{3} \mathrm{~N}_{4} / \mathrm{ZnO}$ hybrid photocatalyst with a higher activity in methylene blue (MB) degradation than either a single phase of $\mathrm{ZnO}$ or $\mathrm{g}-\mathrm{C}_{3} \mathrm{~N}_{4}$. In addition, the excellent antiphotocorrosion ability was also observed from this composite material. Therein, the performance enhancement and the photocorrosion inhibition were attributed to the high separation efficiency of photogenerated charges. Yan et al. [22] reported that the coupling of TaON with $\mathrm{g}-\mathrm{C}_{3} \mathrm{~N}_{4}$ can increase the photocatalytic degradation of rhodamine $\mathrm{B}$ due to an improved electron-hole separation which results from the appropriate band structures of the composite photocatalyst. The organic-inorganic composite of $\mathrm{g}-\mathrm{C}_{3} \mathrm{~N}_{4}$ and $\mathrm{Pt} / \mathrm{TiO}{ }_{2}$ with superior photocatalytic $\mathrm{H}_{2}$ production rate was also observed by Chai et al [17]. The authors ascribed such improved $\mathrm{H}_{2}$ evolution to the direct migration of electrons from $\mathrm{g}-\mathrm{C}_{3} \mathrm{~N}_{4}$ to $\mathrm{Pt} / \mathrm{TiO} 2$ via close interface and the effective separation of photogenerated charge carriers due to the synergistic effect.

In this study, a series of $\mathrm{g}-\mathrm{C}_{3} \mathrm{~N}_{4} / \mathrm{TiO}_{2}$ photocatalyst films with different $\mathrm{g}-\mathrm{C}_{3} \mathrm{~N}_{4}$ loading contents have been investigated for their photodegradation activities towards MB under visible-light illumination $(\lambda>400 \mathrm{~nm})$. The possible mechanism for the enhancement of photocatalytic performance over the $\mathrm{g}-\mathrm{C}_{3} \mathrm{~N}_{4} / \mathrm{TiO}_{2}$ heterostructured photocatalyst was also proposed.

\section{Experimental}

\subsection{Materials}

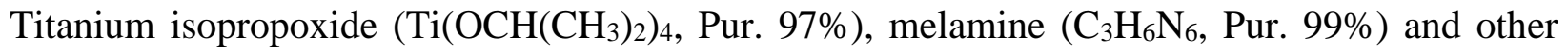
chemicals (analytical grade purity) were purchased from Aldrich and used without further purification. Deionized (DI) water was used throughout this study. 


\subsection{Catalyst preparation}

Pure $\mathrm{TiO}_{2}$ nanoparticles were synthesized by membrane-assisted sol-gel method [23, 24]. Briefly, a $20 \mathrm{ml}$ of titanium tetraisopropoxide (TTIP) was dissolved in $250 \mathrm{ml}$ of absolute ethanol. The mixture was loaded into a cellophane membrane pouch and then placed in a clear solution of 1:1 (v/v) ethanol/DI water containing $1.76 \mathrm{wt} \%$ of $\mathrm{NH}_{4} \mathrm{OH}$. The solution was stirred and heated at $70-80{ }^{\circ} \mathrm{C}$ for $1 \mathrm{~h}$, after which the suspension was then centrifuged, washed with DI water untill pH 7 was obtained and dried at $60{ }^{\circ} \mathrm{C}$ for $24 \mathrm{~h}$. The dried $\mathrm{TiO}_{2}$ powder was then calcined under static air at $400{ }^{\circ} \mathrm{C}$ for $3 \mathrm{~h}$.

The $\mathrm{g}-\mathrm{C}_{3} \mathrm{~N}_{4}$ sample was prepared by directly heating melamine under a flow of Ar gas as described elsewhere [20]. In brief, $3 \mathrm{~g}$ of melamine powder was placed in a semiclosed alumina crucible with a quartz cover. The crucible was then put into a quartz tube reaction chamber and heated at $500{ }^{\circ} \mathrm{C}$ for $2 \mathrm{~h}$ in a flow of Ar. The sample was further heated at $520^{\circ} \mathrm{C}$ for $2 \mathrm{~h}$. Afterward, the obtained yellow polymeric $\mathrm{g}-\mathrm{C}_{3} \mathrm{~N}_{4}$ was ground into powder.

The $\mathrm{g}-\mathrm{C}_{3} \mathrm{~N}_{4} / \mathrm{TiO}_{2}$ composite catalysts were prepared by mixing the pre-synthesized $\mathrm{TiO}_{2}$ with different weight percentages of melamine (the nominal contents of 20, 50 and $70 \mathrm{wt} \%$ ) in ethanol. The slurry mixture was stirred at room temperature for $3 \mathrm{~h}$ and sonicated for $1 \mathrm{~h}$ to obtain the homogeneous mixing. The sample was dried in an oven at $60^{\circ} \mathrm{C}$ for $24 \mathrm{~h}$ and subjected to the heat treatment under the same conditions as those of pure $\mathrm{g}-\mathrm{C}_{3} \mathrm{~N}_{4}$.

\subsection{Characterization}

To identify the crystalline phase of the obtained materials, X-ray diffraction (XRD) experiments were performed on a GBC EMMA 0133 X-ray diffractometer with $\mathrm{Cu}-\mathrm{K}_{\alpha}$ radiation of $0.15406 \mathrm{~nm}$, at a scanning speed of $4 \% \mathrm{~min}$. The morphology and microstructure of the photocatalyst films were examined by field emission scanning electron microscope (FESEM, JSM 
6335F) equipped with energy dispersive X-ray (EDX) spectrometer and transmission electron microscope (TEM, JEOL JEM 2010). Fourier transform infrared (FTIR) spectra were recorded on a Nicolet 510 FTIR spectrometer using conventional $\mathrm{KBr}$ pellets. Thermogravimetric (TG) analysis was done on TA instrument Q10 DSC. The experiment temperature ranged from $20^{\circ} \mathrm{C}$ to $800{ }^{\circ} \mathrm{C}$ at a constant heating rate of $10{ }^{\circ} \mathrm{C} \mathrm{min}-1$ in air. X-ray photoelectron spectroscopy (XPS) measurement was performed using PHOIBOS 100 hemispherical energy analyser (SPECS) equipped with $\mathrm{Al}, \mathrm{K} \alpha$ radiation in the fixed analyser transmission mode. All peaks in XPS spectra have already been calibrated with $\mathrm{C} 1 \mathrm{~s}$ peak at $285 \mathrm{eV}$. UV-vis absorption spectra of all photocatalyst films were analyzed by Shimadzu UV-3600 spectrophotometer equipped with an integrating sphere assembly. Brunauer-Emmett-Teller (BET) surface area measurement was carried out using an Autosorb $1 \mathrm{MP}$, Quantachrome analyzer with $\mathrm{N}_{2}$ adsorption isotherm.

\subsection{Preparation of photocatalyst films}

Photocatalyst films were prepared by doctor blade coating technique [25]. Typically, $1 \mathrm{~g}$ of the as-synthesized powders was mixed with $40 \mu \mathrm{l}$ of acetic acid, $15 \mu \mathrm{l}$ of Triton X100, and 0.5 $\mathrm{ml}$ of Milli Q water. The slurry was ground and sonicated to break up large agglomerates. The film was then prepared on a glass slide $(2.00 \times 5.00 \mathrm{~cm})$ and the film thickness determined by a Veeco Dektak 6M stylus profilometer was $13.0 \pm 2.0 \mu \mathrm{m}$. Finally, the prepared film was annealed at $300^{\circ} \mathrm{C}$ for $1 \mathrm{~h}$ under static air.

\subsection{Photocatalytic experiments}

The photocatalytic activities of catalyst films were evaluated by the decomposition of methylene blue (MB) under visible light illumination $(\lambda>400 \mathrm{~nm})$. A $50 \mathrm{~W}$ Halogen lamp (an intensity of $\sim 640 \mathrm{~W} / \mathrm{m}^{2}$ ) equipped with a $400 \mathrm{~nm}$ cut-off filter was used as a light source. In a 
typical run, an aqueous $\mathrm{MB}$ solution $\left(15 \mathrm{ml}, 10 \mathrm{mg} \mathrm{L}^{-1}\right)$ was added into a batch reactor containing photocatalyst film. The solution $\mathrm{pH}$ was adjusted to $\sim 7.0$ by using $0.1 \mathrm{M} \mathrm{NaOH}$ or $0.1 \mathrm{M} \mathrm{HClO}_{4}$. Prior to light irradiation, the film was kept under the dark for 30 min to achieve adsorptiondesorption equilibrium. At given time intervals, $2 \mathrm{ml}$ samples were taken from the reaction solution and the amount of MB was determined by a Shimadzu UV-1601 spectrophotometer at $664 \mathrm{~nm}$ which corresponds to the characteristic absorption peak of MB. Then, the collected sample was put back into the reactor and the light was then irradiated again.

For comparison, MB photolysis was also investigated under the same experimental conditions. Investigation on the stability of $\mathrm{g}_{-} \mathrm{C}_{3} \mathrm{~N}_{4} / \mathrm{TiO}_{2}$ film was carried out for five successive experiments, using a fresh MB solution for each catalytic run. After each run, the film was washed with deionized water and subsequently annealed at $300^{\circ} \mathrm{C}$ for $1 \mathrm{~h}$.

\section{Results and discussion}

\subsection{TG analysis}

To determine the $\mathrm{g}-\mathrm{C}_{3} \mathrm{~N}_{4}$ contents in the final products, thermogravimetric analysis was performed from $20^{\circ} \mathrm{C}$ to $800{ }^{\circ} \mathrm{C}$ in air. As shown in Fig. 1, pure $\mathrm{TiO}_{2}$ shows almost no weight loss in the temperature range of study. However, pure $\mathrm{g}_{-} \mathrm{C}_{3} \mathrm{~N}_{4}$ presents the rapid weight loss from 550 ${ }^{\circ} \mathrm{C}$ to $670{ }^{\circ} \mathrm{C}$, indicating the sublimation and/or decomposition of $\mathrm{g}-\mathrm{C}_{3} \mathrm{~N}_{4}$. The weight of the $\mathrm{g}$ $\mathrm{C}_{3} \mathrm{~N}_{4} / \mathrm{TiO}_{2}$ composites decreases rapidly at the temperature above $500{ }^{\circ} \mathrm{C}$. At the end of the analysis, total combustion of $\mathrm{g}-\mathrm{C}_{3} \mathrm{~N}_{4}$ is attained. Therefore, the weight loss can be directly related to the amount of $\mathrm{g}-\mathrm{C}_{3} \mathrm{~N}_{4}$ in the composite. The results from TG study indicate that the $\mathrm{g}-\mathrm{C}_{3} \mathrm{~N}_{4}$ contents in the respective composites correspond to the nominal values.

\section{[Fig. 1, single column fitting image]}




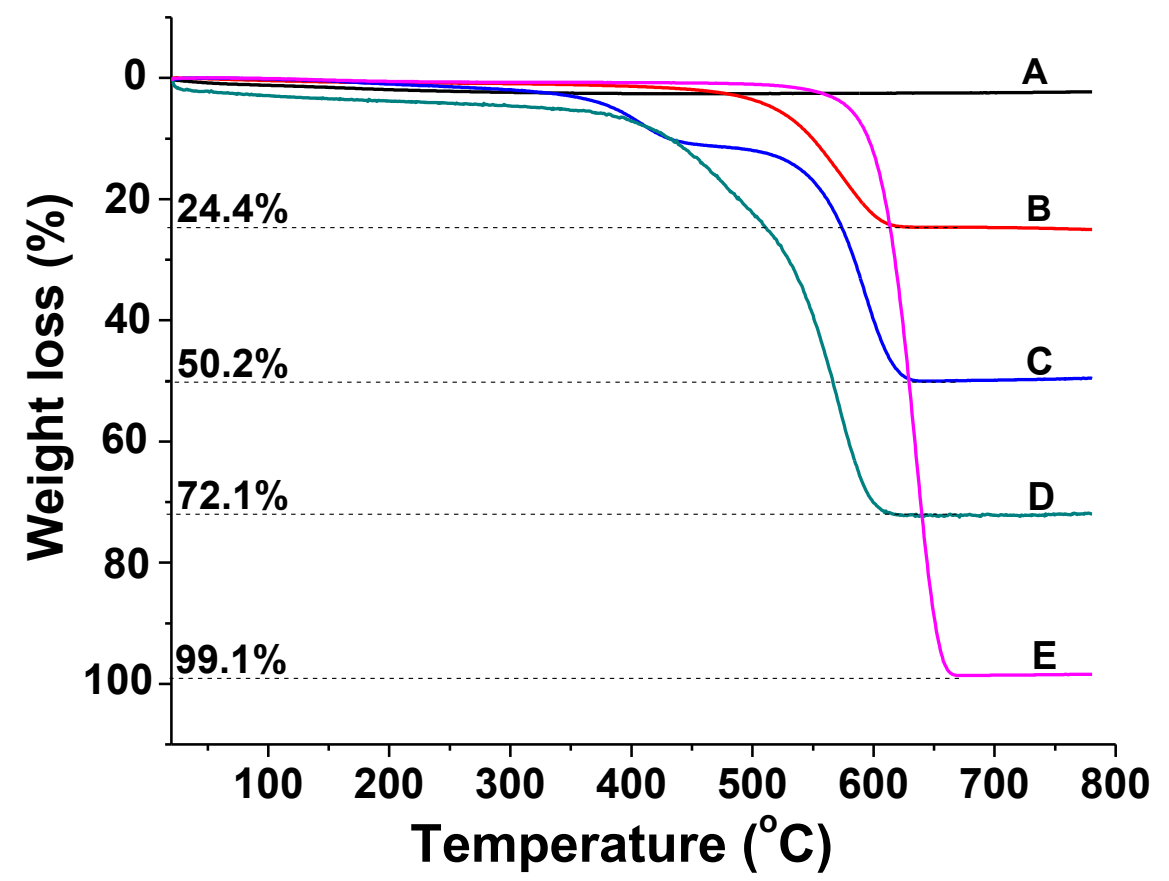

Fig. 1. Thermogravimetric analysis of (A) pure $\mathrm{TiO}_{2}$, (B) $20 \mathrm{wt} \% \mathrm{~g}-\mathrm{C}_{3} \mathrm{~N}_{4} / \mathrm{TiO}_{2}$, (C) $50 \mathrm{wt} \% \mathrm{~g}-$ $\mathrm{C}_{3} \mathrm{~N}_{4} / \mathrm{TiO}_{2}$, (D) $70 \mathrm{wt} \% \mathrm{~g}-\mathrm{C}_{3} \mathrm{~N}_{4} / \mathrm{TiO}_{2}$ and (E) pure g- $\mathrm{C}_{3} \mathrm{~N}_{4}$.

\subsection{Crystal phases and microstructure analyses}

Powder XRD patterns of pure $\mathrm{TiO}_{2}$, pure $\mathrm{g}-\mathrm{C}_{3} \mathrm{~N}_{4}$ and $\mathrm{g}-\mathrm{C}_{3} \mathrm{~N}_{4} / \mathrm{TiO}_{2}$ composites are shown in Fig. 2. The diffraction peak of pure $\mathrm{g}-\mathrm{C}_{3} \mathrm{~N}_{4}$ at $2 \theta$ of $\sim 27.4^{\circ}$ is the characteristic of interlayer stacking of conjugated aromatic system, indexed as the (002) diffraction plane for graphitic materials [26]. The calculated interplanar distance of aromatic units is $\sim 0.33 \mathrm{~nm}$ which is in good agreement with the previous reports [27-29]. The peaks of pure $\mathrm{TiO}_{2}$ at $25.3^{\circ}, 37.8^{\circ}, 48.0^{\circ}, 53.9^{\circ}$, $55.1^{\mathrm{o}}, 62.7^{\mathrm{o}}$ and $68.7^{\mathrm{o}}$ correspond to the (101), (004), (200), (105), (211), (204) and (116) crystal planes of anatase $\mathrm{TiO}_{2}$ (JCPDS 21-1272) [23]. The XRD patterns of $\mathrm{g}-\mathrm{C}_{3} \mathrm{~N}_{4} / \mathrm{TiO}_{2}$ composites show no obvious diffraction peak attributable to $g-\mathrm{C}_{3} \mathrm{~N}_{4}$ when the $\mathrm{g}-\mathrm{C}_{3} \mathrm{~N}_{4}$ content is less than 50 wt\%; however the composites with higher $\mathrm{g}-\mathrm{C}_{3} \mathrm{~N}_{4}$ loading clearly display the diffraction peak of $\mathrm{g}-\mathrm{C}_{3} \mathrm{~N}_{4}$ 
at $\sim 27.4^{\circ}$. It can also be seen that the relative peak intensity of $g-\mathrm{C}_{3} \mathrm{~N}_{4}$ gradually improves upon increasing the $\mathrm{g}-\mathrm{C}_{3} \mathrm{~N}_{4}$ content.

\section{[Fig. 2, single column fitting image]}

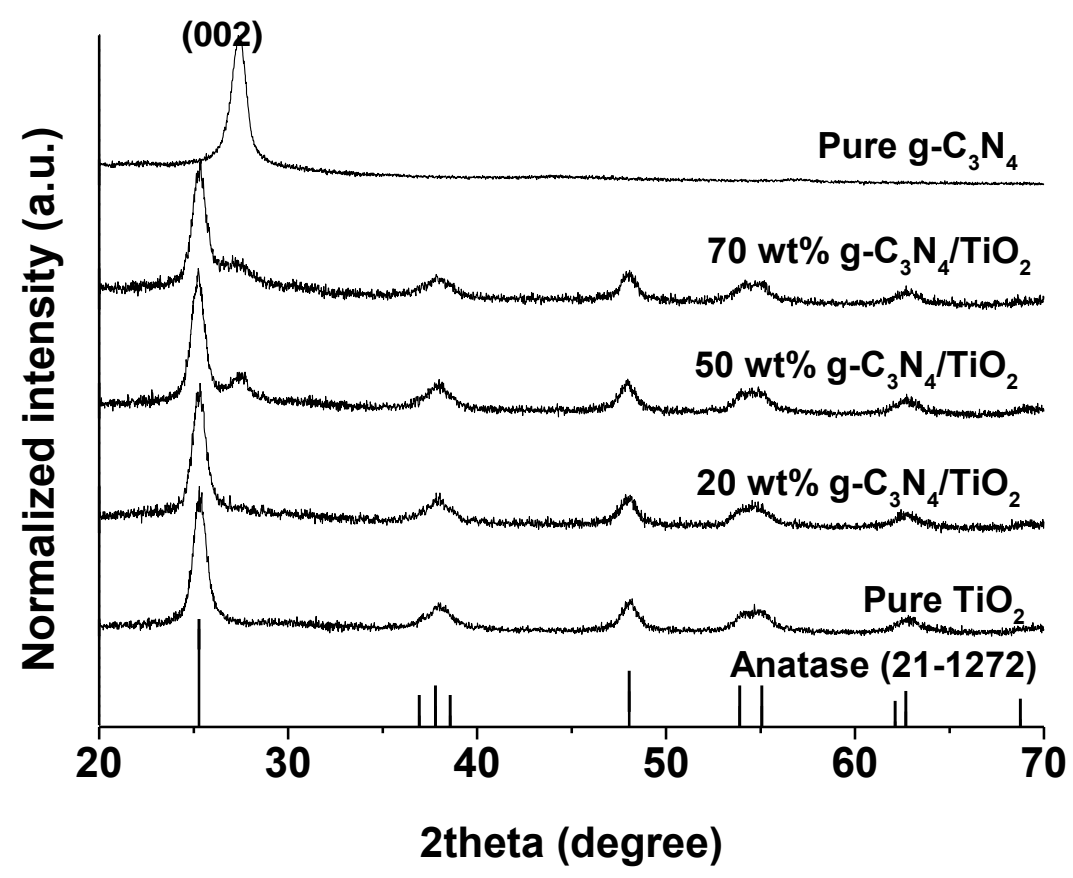

Fig. 2. XRD patterns of pure $\mathrm{TiO}_{2}$, pure $\mathrm{g}-\mathrm{C}_{3} \mathrm{~N}_{4}$ and $\mathrm{g}-\mathrm{C}_{3} \mathrm{~N}_{4} / \mathrm{TiO}_{2}$ composites.

Morphology and microstructure of the catalyst films were examined by FESEM and TEM. Fig. 3 shows FESEM micrographs of pure g- $\mathrm{C}_{3} \mathrm{~N}_{4}$, pure $\mathrm{TiO}_{2}$ and $\mathrm{g}-\mathrm{C}_{3} \mathrm{~N}_{4} / \mathrm{TiO}_{2}$ composite films. The g- $\mathrm{C}_{3} \mathrm{~N}_{4}$ (Fig. 3a) appears as aggregated irregular particles whereas pure $\mathrm{TiO}_{2}$ (Fig. 3b) presents as agglomerates of small spherical-like particles. The FESEM image (Fig. 3c) of $50 \mathrm{wt} \% \mathrm{~g}$ $\mathrm{C}_{3} \mathrm{~N}_{4} / \mathrm{TiO}_{2}$ together with the corresponding EDX spectrum (Fig. 3d) reveals the agglomeration morphology and the attachment of the $\mathrm{TiO}_{2}$ particles on the g- $\mathrm{C}_{3} \mathrm{~N}_{4}$ surfaces. Fig.4 shows the TEM micrographs of pure g- $\mathrm{C}_{3} \mathrm{~N}_{4}$, pure $\mathrm{TiO}_{2}$ and $\mathrm{g}-\mathrm{C}_{3} \mathrm{~N}_{4} / \mathrm{TiO}_{2}$ composites. It can be seen that $\mathrm{g}-\mathrm{C}_{3} \mathrm{~N}_{4}$ (Fig. 4a) displays 2D lamellar structure whereas pure $\mathrm{TiO}_{2}$ (Fig. 4b) shows spherical particles with an average particle size of $13.7 \mathrm{~nm}$. For the $50 \mathrm{wt} \% \mathrm{~g}-\mathrm{C}_{3} \mathrm{~N}_{4} / \mathrm{TiO}_{2}$ composite (Fig. $4 \mathrm{c}$ ), the $\mathrm{TiO}_{2}$ 
nanoparticles are found embedded in the $\mathrm{g}-\mathrm{C}_{3} \mathrm{~N}_{4}$ lamellar structure. The corresponding HRTEM image (Fig. 4d) clearly reveals the close interfacial connections between $g-\mathrm{C}_{3} \mathrm{~N}_{4}$ and $\mathrm{TiO}_{2}$ nanoparticles as well as the lattice spacing of $0.32 \mathrm{~nm}$, corresponding to the (101) plane of anatase $\mathrm{TiO}_{2}$. These observations together with the SEM result in Fig. 3c suggest the formation of heterojunction between $\mathrm{TiO}_{2}$ and $\mathrm{g}-\mathrm{C}_{3} \mathrm{~N}_{4}$ which would be an ideal system to achieve the improved electron-hole separation via smooth charge transfer process [29].

\section{[Fig. 3, single column fitting image]}

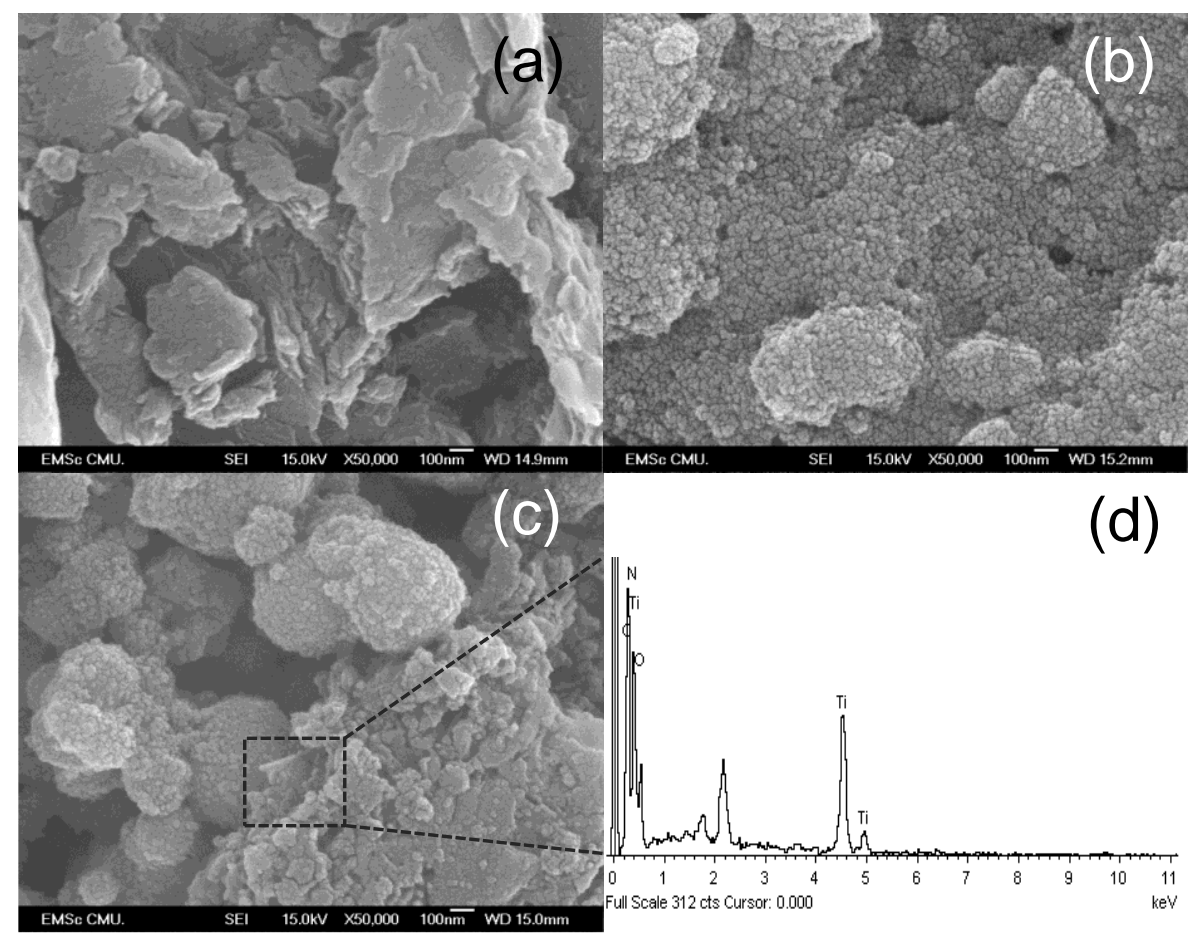

Fig. 3. FESEM images of (a) pure $\mathrm{g}-\mathrm{C}_{3} \mathrm{~N}_{4}$, (b) pure $\mathrm{TiO}_{2}$ and (c) $50 \mathrm{wt} \% \mathrm{~g}-\mathrm{C}_{3} \mathrm{~N}_{4} / \mathrm{TiO}_{2}$ composite films and (d) the corresponding EDX spectrum of (c).

\section{[Fig. 4, single column fitting image]}




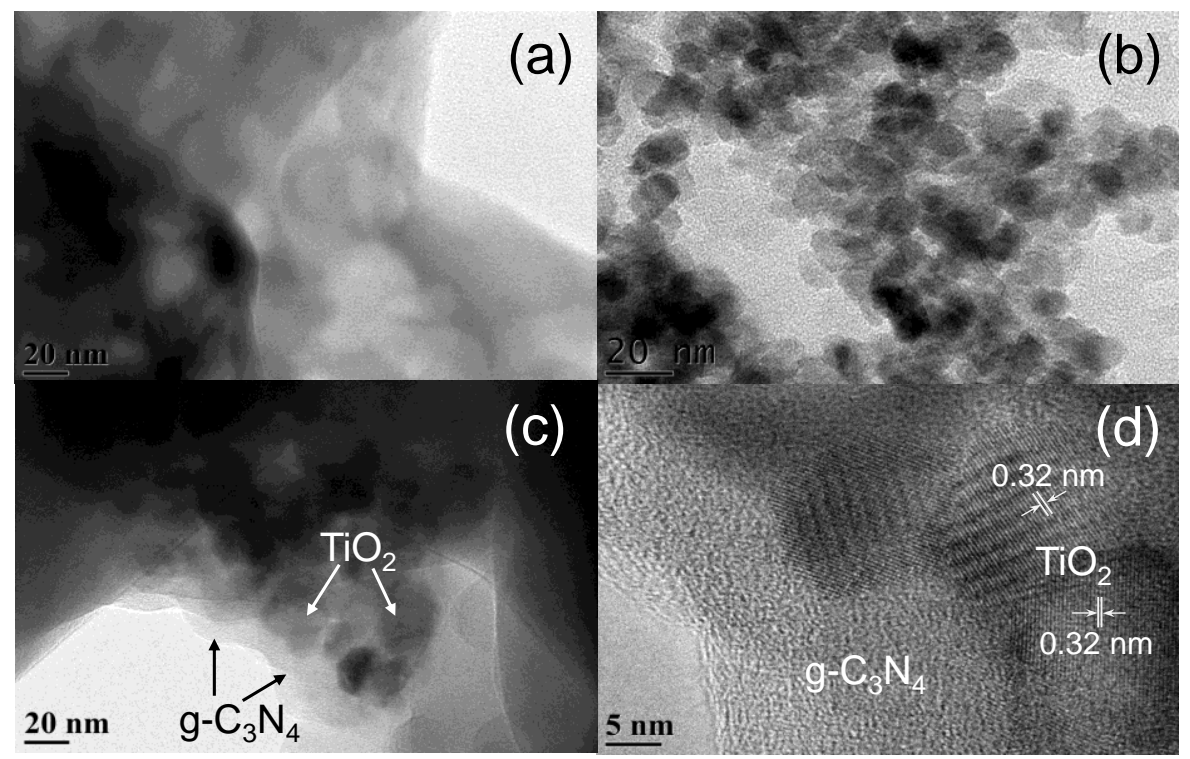

Fig. 4. TEM micrographs of (a) pure $\mathrm{g}-\mathrm{C}_{3} \mathrm{~N}_{4}$, (b) pure $\mathrm{TiO}_{2}$ and (c,d) $50 \mathrm{wt} \% \mathrm{~g}-\mathrm{C}_{3} \mathrm{~N}_{4} / \mathrm{TiO}_{2}$ composite.

\subsection{FTIR analysis}

FTIR spectra of $\mathrm{g}-\mathrm{C}_{3} \mathrm{~N}_{4}, \mathrm{TiO}_{2}$ and $\mathrm{g}-\mathrm{C}_{3} \mathrm{~N}_{4} / \mathrm{TiO}_{2}$ composites with different $\mathrm{g}-\mathrm{C}_{3} \mathrm{~N}_{4}$ contents are presented in Fig. 5. Pure $\mathrm{g}-\mathrm{C}_{3} \mathrm{~N}_{4}$ shows characteristic IR peaks similar to those of the previous results $[17,21,22,30,31]$. The peak at $1640 \mathrm{~cm}^{-1}$ is assigned to $\mathrm{C}-\mathrm{N}$ stretching vibration mode, while those at $1247,1325,1408 \mathrm{~cm}^{-1}$ are associated with $\mathrm{C}-\mathrm{N}$ heterocycle stretching of $\mathrm{g}-\mathrm{C}_{3} \mathrm{~N}_{4}$ $[17,21]$. The peak at $810 \mathrm{~cm}^{-1}$ can be attributed to the characteristic breathing mode of triazine units [21]. A broad band in the range of $3150-3300 \mathrm{~cm}^{-1}$ corresponds to the stretching vibration modes of terminal NH groups [30]. Pure $\mathrm{TiO}_{2}$ shows characteristic broad absorption band at 500$700 \mathrm{~cm}^{-1}$ [17]. It can be clearly seen that the main characteristic peaks of $\mathrm{g}-\mathrm{C}_{3} \mathrm{~N}_{4}$ and $\mathrm{TiO}_{2}$ appeared in all g- $\mathrm{C}_{3} \mathrm{~N}_{4} / \mathrm{TiO}_{2}$ samples suggesting the formation of a composite between $\mathrm{g}-\mathrm{C}_{3} \mathrm{~N}_{4}$ and $\mathrm{TiO}_{2}[32]$.

[Fig. 5, single column fitting image] 


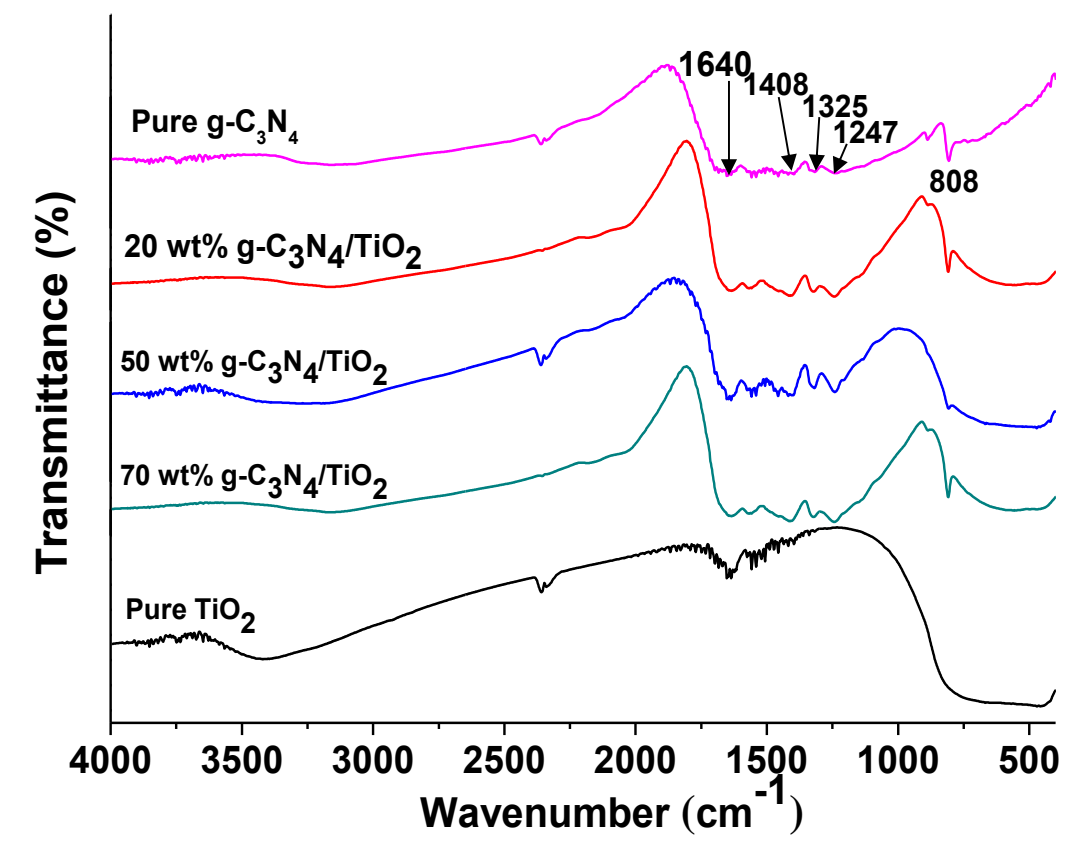

Fig. 5. FTIR spectra of pure g- $\mathrm{C}_{3} \mathrm{~N}_{4}$, pure $\mathrm{TiO}_{2}$ and $\mathrm{g}-\mathrm{C}_{3} \mathrm{~N}_{4} / \mathrm{TiO}_{2}$ composites.

\subsection{XPS analysis}

XPS measurement was carried out to obtain the information on oxidation state and surface chemical composition of the samples. Survey spectra in Fig. 6a indicate the peaks of Ti, O, C, and $\mathrm{N}$ in the $50 \mathrm{wt} \% \mathrm{~g}-\mathrm{C}_{3} \mathrm{~N}_{4} / \mathrm{TiO}_{2}$ composite and the peaks of $\mathrm{Ti}, \mathrm{O}$ and $\mathrm{C}$ in the pure $\mathrm{TiO}_{2}$. The $\mathrm{C} 1 \mathrm{~s}$ XPS spectrum of $\mathrm{g}-\mathrm{C}_{3} \mathrm{~N}_{4} / \mathrm{TiO}_{2}$ sample (Fig. 6b) displays four peaks centering at 285.0, 286.4, 288.5 and $294.0 \mathrm{eV}$. The peak at $285.0 \mathrm{eV}$ can be ascribed to $\mathrm{C}-\mathrm{C}$ and/or adventitious carbon, and the peaks at 286.4 and $288.5 \mathrm{eV}$ can be assigned to $\mathrm{C}-\mathrm{N}-\mathrm{C}$ and $\mathrm{C}-(\mathrm{N})_{3}$ groups of $\mathrm{g}-\mathrm{C}_{3} \mathrm{~N}_{4}[33,34]$, respectively. Another $\mathrm{C} 1 \mathrm{~s}$ peak found at higher energy $c a .294 .0 \mathrm{eV}$ is attributed to carbon in aromatic rings attached to terminal uncondensed $\mathrm{NH}_{2}$ species [34]. The regional spectrum of $\mathrm{N} 1 \mathrm{~s}$ for $\mathrm{g}-\mathrm{C}_{3} \mathrm{~N}_{4} / \mathrm{TiO}_{2}$ also presents in Fig. $6 \mathrm{c}$. The spectrum can be deconvoluted into four peaks, ascribable to O-Ti-N in $\mathrm{TiO}_{2-\mathrm{x}} \mathrm{N}_{\mathrm{x}}$ at $396.2 \mathrm{eV}$ [35], $\mathrm{C}-\mathrm{N}=\mathrm{C}$ at $398.6 \mathrm{eV}$ [36], N-(C) 3 at $399.3 \mathrm{eV}$ $[17,34,36]$ and $-\mathrm{NH}_{2}$ or $=\mathrm{NH}$ of uncondensed terminal amino groups at $401.0 \mathrm{eV}$ [37]. 
Fig. 6d shows Ti $2 p$ spectra of pure $\mathrm{TiO}_{2}$ in comparison with that of $50 \mathrm{wt} \% \mathrm{~g}-\mathrm{C}_{3} \mathrm{~N}_{4} / \mathrm{TiO}_{2}$. The binding energy values of $\mathrm{Ti} 2 \mathrm{p}_{3 / 2}$ and $\mathrm{Ti} 2 \mathrm{p}_{1 / 2}$ at 458.9 and $464.7 \mathrm{eV}$, respectively can be ascribed to $\mathrm{Ti}^{4+}$ species in the form of $\mathrm{TiO}_{2}$ clusters [33]. However, the shift of $0.4 \mathrm{eV}$ to the lower binding energies of 458.5 and $464.3 \mathrm{eV}$, respectively, is observed for the $50 \mathrm{wt} \% \mathrm{~g}-\mathrm{C}_{3} \mathrm{~N}_{4} / \mathrm{TiO}_{2}$. This negative shift could be ascribed to an enhanced partial electron transformation to Ti and an increased electron density on $\mathrm{Ti}[38]$ as a consequence of the electronegativity effect due to the electronic interactions between $\mathrm{Ti}$ and possibly $\mathrm{N}$ atom as supported by the peak of $\mathrm{O}-\mathrm{Ti}-\mathrm{N}$ in $\mathrm{N}$ 1s region. The $\mathrm{O}$ 1s spectrum (Fig. 6e) of pure $\mathrm{TiO}_{2}$ can be fitted into two peaks, and the binding energies of 530.0 and $531.4 \mathrm{eV}$ can be ascribed to oxygen in $\mathrm{TiO}_{2}$ and surface hydroxyls, respectively $[17,38]$. In comparison with pure $\mathrm{TiO}_{2}$, the negative shift of the main $\mathrm{O} 1 \mathrm{~s}$ to 529.6 $\mathrm{eV}$, with an order of $\sim 0.4 \mathrm{eV}$, is observed for the $\mathrm{g}-\mathrm{C}_{3} \mathrm{~N}_{4} / \mathrm{TiO}_{2}$ sample. This shift is the same order as that found in the case of $\mathrm{Ti} 2 \mathrm{p}$ peak position, suggesting the incorporation of nitrogen in $\mathrm{TiO}_{2}$ lattice [38]. The XPS results together with those from SEM, TEM and FTIR studies clearly reveal the formation of composite material with the chemically bound interfaces between $\mathrm{g}-\mathrm{C}_{3} \mathrm{~N}_{4}$ and $\mathrm{TiO}_{2}$ rather than a physical mixture of two separate $\mathrm{g}-\mathrm{C}_{3} \mathrm{~N}_{4}$ and $\mathrm{TiO}_{2}$ phases.

\section{[Fig. 6, 2- column fitting image]}



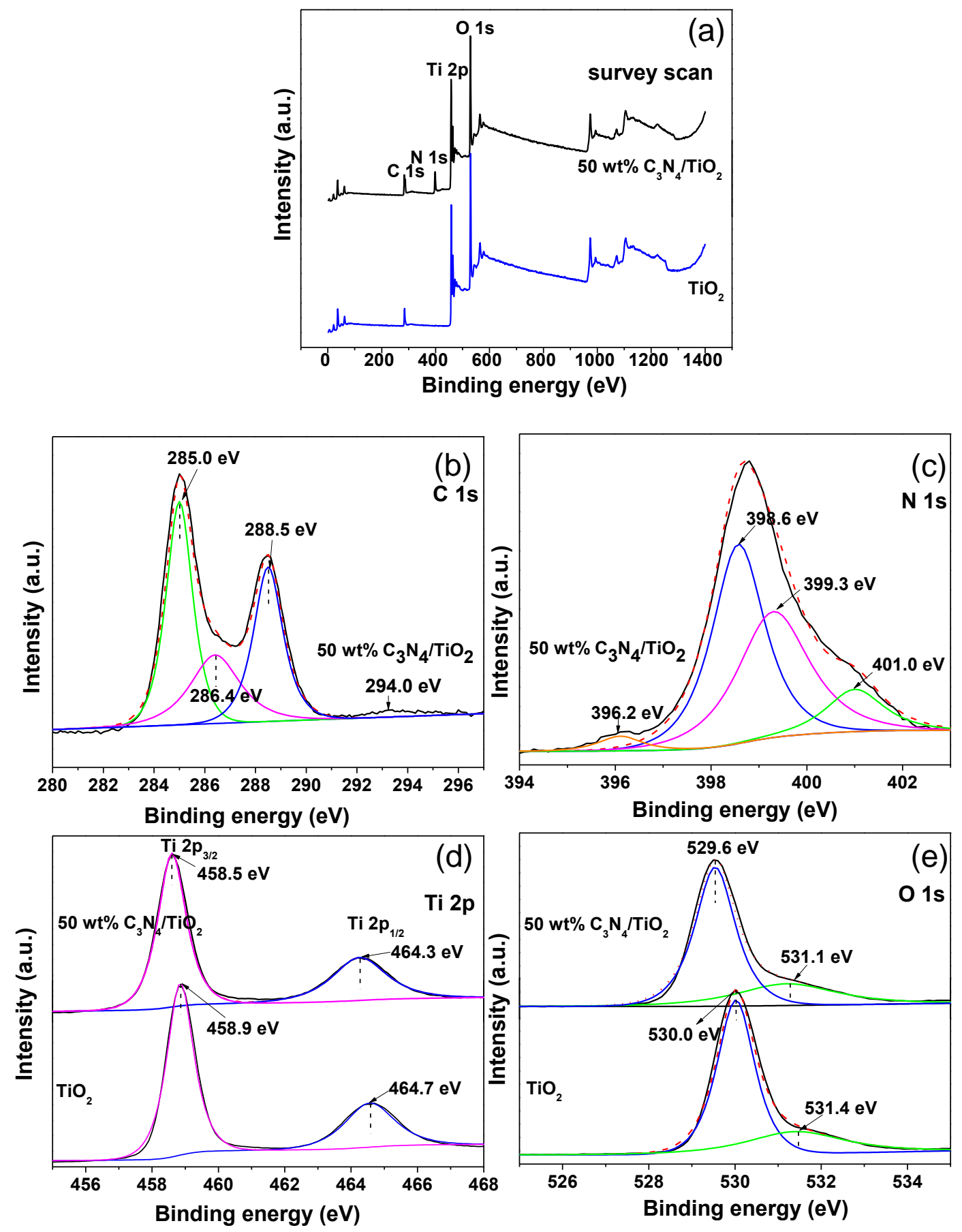

Fig. 6. (a) Survey scan of $\mathrm{TiO}_{2}$ and $50 \mathrm{wt} \% \mathrm{~g}-\mathrm{C}_{3} \mathrm{~N}_{4} / \mathrm{TiO}_{2}$ composite and high-resolution spectra for: (b) $\mathrm{C} 1 \mathrm{~s}$ and (c) $\mathrm{N}$ 1s of $50 \mathrm{wt} \% \mathrm{~g}-\mathrm{C}_{3} \mathrm{~N}_{4} / \mathrm{TiO}_{2}$; (d) $\mathrm{Ti} 2 \mathrm{p}$ and (e) $\mathrm{O} 1 \mathrm{~s}$ of $50 \mathrm{wt} \% \mathrm{~g}-$ $\mathrm{C}_{3} \mathrm{~N}_{4} / \mathrm{TiO}_{2}$ in comparison with those of $\mathrm{TiO}_{2}$. 


\subsection{UV-vis Absorption Spectra}

The optical properties of the photocatalyst films were investigated by UV-vis absorption spectroscopy. As seen from Fig. 7a, the film color changes from opaque white to bright yellow as the amount of $\mathrm{g}-\mathrm{C}_{3} \mathrm{~N}_{4}$ loading increased from 0 to $100 \mathrm{wt} \%$. The optical spectra of the films (Fig. 7b) present the absorption onsets at $\sim 375 \mathrm{~nm}$ and $\sim 490 \mathrm{~nm}$ for pure $\mathrm{TiO}_{2}$ and $\mathrm{g}-\mathrm{C}_{3} \mathrm{~N}_{4}$, respectively. Superior light absorption intensity compared with pure $\mathrm{TiO}_{2}$ is found from all $\mathrm{g}-\mathrm{C}_{3} \mathrm{~N}_{4} / \mathrm{TiO}_{2}$ composite films. Additionally, upon loading $\mathrm{TiO}_{2}$ with $\mathrm{g}-\mathrm{C}_{3} \mathrm{~N}_{4}$, the light absorption region of $\mathrm{TiO}_{2}$ could be further extended to longer wavelength and the highest red shift appearing at $\sim 540 \mathrm{~nm}$ is found from $50 \mathrm{wt} \% \mathrm{~g}-\mathrm{C}_{3} \mathrm{~N}_{4} / \mathrm{TiO}_{2}$ sample. These observations suggest that the composite catalyst could provide an efficient utilization of visible light, thus producing more electron-hole pair, which would be beneficial to a photocatalytic process. The band gap energy $\left(E_{g}\right)$ of a semiconductor can be determined by Equation (1):

$(\alpha h v)^{1 / n}=A\left(h v-E_{g}\right)$

where $A$ is a proportionality constant, $h v$ is photon energy, $h$ is Planck's constant, $v$ is the frequency of vibration, and $\alpha$ is an absorption coefficient. The value of $n$ depends on the type of optical transition of the semiconductor ( $n=1 / 2$ for direct transition and $n=2$ for indirect transition). For g- $\mathrm{C}_{3} \mathrm{~N}_{4}$ and $\mathrm{TiO}_{2}$, the $n$ values of $1 / 2$ and 2 are used, respectively [39-41]. Therefore, as can be seen from the inset of Fig. 7b, the corresponding band gap values of $\mathrm{g}_{-} \mathrm{C}_{3} \mathrm{~N}_{4}$ and $\mathrm{TiO}_{2}$ are found to be 2.83 and $3.31 \mathrm{eV}$, respectively.

\section{[Fig. 7, single column fitting image]}



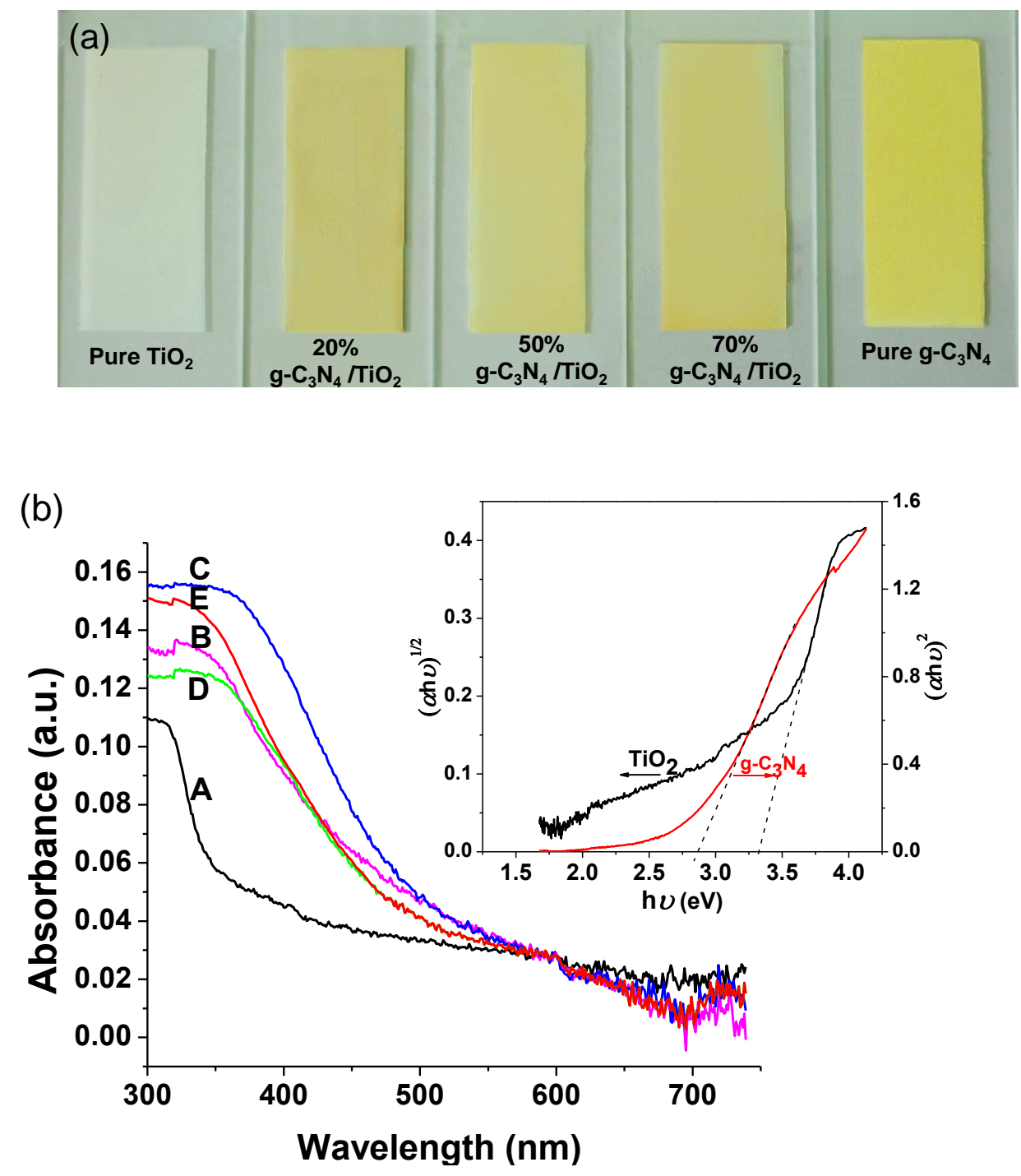

Fig. 7. (a) Photocatalyst films and (b) UV-vis absorption spectra of (A) pure $\mathrm{TiO}_{2}$, (B) $20 \mathrm{wt} \%$ g$\mathrm{C}_{3} \mathrm{~N}_{4} / \mathrm{TiO}_{2}$, (C) $50 \mathrm{wt} \% \mathrm{~g}-\mathrm{C}_{3} \mathrm{~N}_{4} / \mathrm{TiO}_{2}$, (D) $70 \mathrm{wt} \% \mathrm{~g}-\mathrm{C}_{3} \mathrm{~N}_{4} / \mathrm{TiO}_{2}$ and (E) pure $\mathrm{g}-\mathrm{C}_{3} \mathrm{~N}_{4}$ films. Inset is $(\alpha h v)^{1 / 2}$ and $(\alpha h v)^{2} v s$ photon energy $(h v)$ plot of pure $\mathrm{TiO}_{2}$ and $\mathrm{g}-\mathrm{C}_{3} \mathrm{~N}_{4}$ films, respectively.

\subsection{Photocatalytic Activities of the photocatalyst films}

The photocatalytic activities of the obtained films were evaluated by measuring the decolorization of $\mathrm{MB}$ under visible light irradiation $(\lambda>400 \mathrm{~nm})$. As a comparison, direct photolysis and photocatalytic degradation of $\mathrm{MB}$ over pure $\mathrm{TiO}_{2}$ were also carried out under identical conditions. Unfortunately, $\mathrm{MB}$ degradation activity over pure $\mathrm{g}-\mathrm{C}_{3} \mathrm{~N}_{4}$ film was not obtained due to the 
problems with film-peeling off. As seen from Fig. 8a, the blank test without any catalyst shows the $\mathrm{MB}$ degradation of $\sim 28 \%$ whereas the pure $\mathrm{TiO}_{2}$ film provides $\sim 35 \%$ degradation within $3 \mathrm{~h}$ of irradiation. The photocatalytic activity of $\mathrm{g}-\mathrm{C}_{3} \mathrm{~N}_{4} / \mathrm{TiO}_{2}$, however, is much better than that of the pure $\mathrm{TiO}_{2}$ sample, although at high $\mathrm{g}-\mathrm{C}_{3} \mathrm{~N}_{4}$ concentration the activity decreases slightly, suggesting an optimum $\mathrm{g}-\mathrm{C}_{3} \mathrm{~N}_{4}$ content of $50 \mathrm{wt} \%$. The $50 \mathrm{wt} \% \mathrm{~g}-\mathrm{C}_{3} \mathrm{~N}_{4} / \mathrm{TiO}_{2}$ film can degrade $\mathrm{MB}$ by $68 \%$ which is almost twice higher than that of pure $\mathrm{TiO}_{2}$. The improved photocatalytic activity observed from the $\mathrm{g}-\mathrm{C}_{3} \mathrm{~N}_{4} / \mathrm{TiO}_{2}$ films might be partially ascribed to the red-shift of the light absorption range and the strong light absorption intensity of the $\mathrm{g}_{-} \mathrm{C}_{3} \mathrm{~N}_{4} / \mathrm{TiO}_{2}$ composites as evidenced from the UV-vis study in Fig. 7b. Another possible reason responsible for the significant enhancement of the photocatalytic performance can be attributed to an improved charge separation efficiency of photogenerated electron-hole pairs due to the suitably matching conduction and valence band levels and the close interfacial connection between $\mathrm{TiO}_{2}$ and $\mathrm{g}-\mathrm{C}_{3} \mathrm{~N}_{4}$ in the composite material [17, 21, 22]. Note that the decrease of BET specific surface area (SSA) with the increase of $g-\mathrm{C}_{3} \mathrm{~N}_{4}$ loading content is observed. The $\mathrm{SSA}$ of pure $\mathrm{TiO}_{2}$ is $120 \mathrm{~m}^{2} / \mathrm{g}$ whereas that of pure $\mathrm{g}-\mathrm{C}_{3} \mathrm{~N}_{4}$ is 6 $\mathrm{m}^{2} / \mathrm{g}$. Upon increasing the $\mathrm{g}-\mathrm{C}_{3} \mathrm{~N}_{4}$ loading to 20,50 and $70 \mathrm{wt} \%$, the surface area decreases to 91 , 49 and $31 \mathrm{~m}^{2} / \mathrm{g}$, respectively. Therefore, the SSA is likely not a main factor governing the observed photocatalytic activity. Since the $50 \mathrm{wt} \% \mathrm{~g}_{-} \mathrm{C}_{3} \mathrm{~N}_{4} / \mathrm{TiO}_{2}$ composite provides the best performance, this sample is selected for the following long-term stability experiments which will be an advantage for practical applications. The cyclic experiments (Fig. 8b) indicate only 5\% deactivation after five cycles, suggesting good stability and recyclability of the $\mathrm{g}^{-} \mathrm{C}_{3} \mathrm{~N}_{4} / \mathrm{TiO}_{2}$ composite film during MB photodegradation reaction.

[Fig. 8, single column fitting image] 

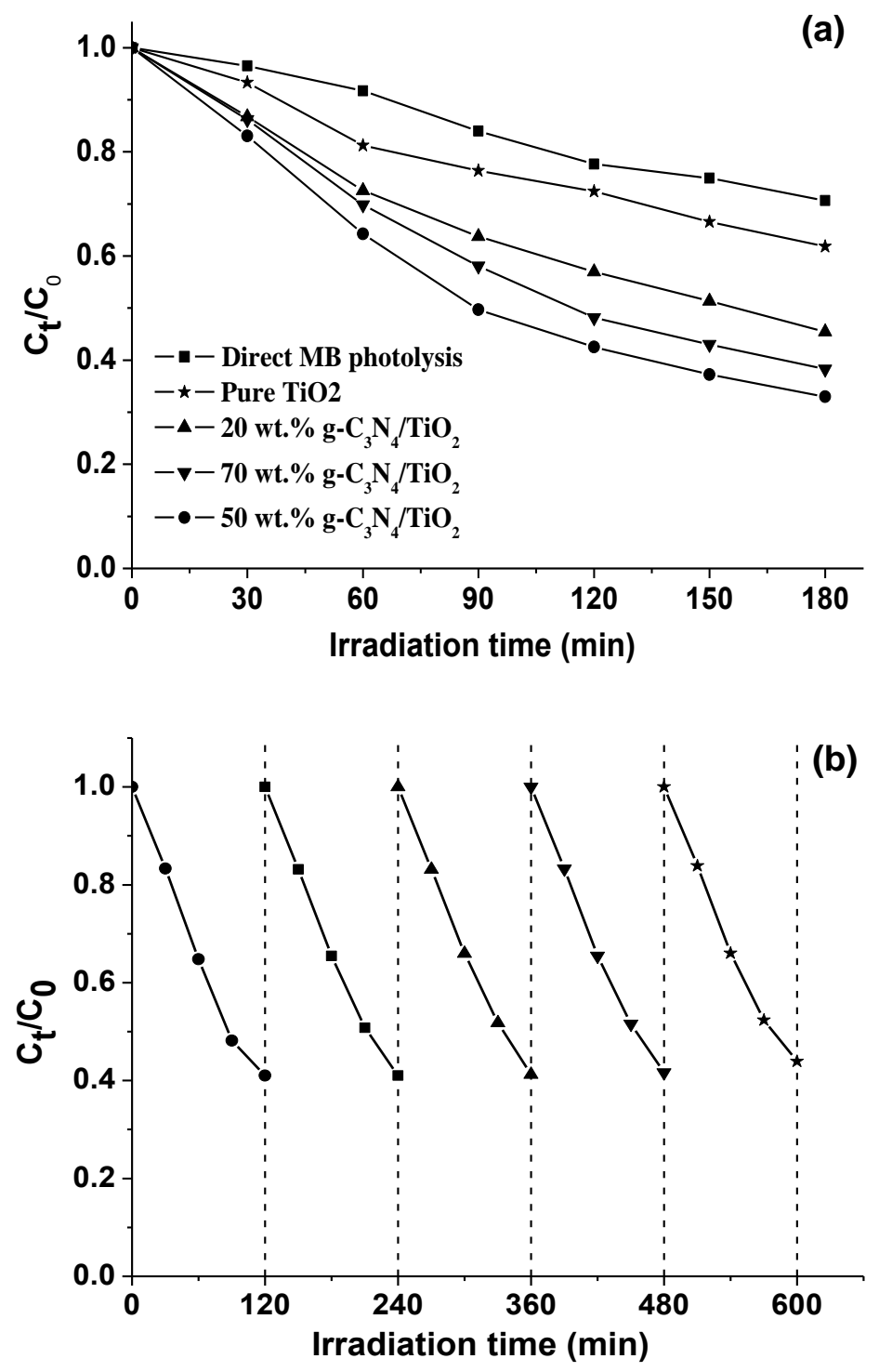

Fig. 8. (a) $\mathrm{MB}$ photolysis and photocatalytic degradation over pure $\mathrm{TiO}_{2}$, pure $\mathrm{g}-\mathrm{C}_{3} \mathrm{~N}_{4}$ and g$\mathrm{C}_{3} \mathrm{~N}_{4} / \mathrm{TiO}_{2}$ composite films and (b) cycling runs using $50 \mathrm{wt} \% \mathrm{~g}-\mathrm{C}_{3} \mathrm{~N}_{4} / \mathrm{TiO}_{2}$ film (the initial MB concentration of $10.0 \mathrm{mg} / \mathrm{L})$.

A proposed mechanism for electron-hole separation and transport at the $\mathrm{g}_{-} \mathrm{C}_{3} \mathrm{~N}_{4} / \mathrm{TiO}_{2}$ interfaces under visible light irradiation is illustrated in Fig. 9. Based on the UV-vis results in Fig. $7 \mathrm{~b}$, the conduction band (CB) and valence band (VB) potentials of $\mathrm{g}_{-} \mathrm{C}_{3} \mathrm{~N}_{4}$ and $\mathrm{TiO}_{2}$ can be determined using Equation (2) [42]: 
$E_{C B}^{0}=\chi-E^{C}-1 / 2 E_{g}$

where $\chi$ is the Sanderson electronegativity of the semiconductor ( $\chi$ is $4.73 \mathrm{eV}[26]$ and $5.81 \mathrm{eV}$ [38] for $\mathrm{g}-\mathrm{C}_{3} \mathrm{~N}_{4}$ and $\mathrm{TiO}_{2}$, respectively), $E^{C}$ is the scaling factor relating the hydrogen electrode scale (NHE) to absolute vacuum scale (AVS) ( $4.5 \mathrm{eV} v s$. AVS for $0 \mathrm{~V} v s$. NHE) [42] and $E_{g}$ is the band gap of $\mathrm{g}-\mathrm{C}_{3} \mathrm{~N}_{4}(2.83 \mathrm{eV})$ and $\mathrm{TiO}_{2}(3.31 \mathrm{eV})$ obtained in this study. The calculated $\mathrm{CB}$ and $\mathrm{VB}$ potentials of $\mathrm{g}-\mathrm{C}_{3} \mathrm{~N}_{4}$ are -1.19 and $1.65 \mathrm{~V}$, and of $\mathrm{TiO}_{2}$ are -0.35 and $2.97 \mathrm{~V}$, respectively. According to the obtained band gap energies, only $\mathrm{g}_{-} \mathrm{C}_{3} \mathrm{~N}_{4}$ can be activated under the visible light illumination, resulting in the photogenerated electrons in the CB and holes in the VB of $g-\mathrm{C}_{3} \mathrm{~N}_{4}$. Because the $\mathrm{CB}$ edge potential of $\mathrm{g}_{-} \mathrm{C}_{3} \mathrm{~N}_{4}(-1.19 \mathrm{~V})$ is more negative than that of $\mathrm{TiO}_{2}(-0.35 \mathrm{~V})$, the electrons in $\mathrm{g}_{-} \mathrm{C}_{3} \mathrm{~N}_{4}$ can transfer easily to the $\mathrm{CB}$ of $\mathrm{TiO}_{2}$ possibly via close interfacial connections $[17,22]$ as supported by the SEM and TEM results, while the holes remain in the VB of $\mathrm{g}-\mathrm{C}_{3} \mathrm{~N}_{4}$. This direct electron transfer from $\mathrm{g}_{-} \mathrm{C}_{3} \mathrm{~N}_{4}$ to $\mathrm{TiO}_{2}$ could reduce the probability of electron-hole recombination [40], leading to efficient charge separation and the improvement of photocatalytic activity as seen in Figure 8a.

Since the CB potential of $\mathrm{TiO}_{2}(-0.35 \mathrm{~V})$ is more negative than the standard redox potential $E^{0}$ $\left(\mathrm{O}_{2} / \bullet \mathrm{O}_{2}^{-},-0.33 \mathrm{~V}\right)[43]$, the electrons accumulated in the $\mathrm{CB}$ of $\mathrm{TiO}_{2}$ can be transferred to adsorbed oxygen molecules yielding $\cdot \mathrm{O}_{2}{ }^{-}$which then further react to finally produce active $\bullet \mathrm{OH}$ radical as follows [29]:

$$
\begin{aligned}
& \mathrm{e}^{-}+\mathrm{O}_{2} \rightarrow \cdot \mathrm{O}_{2}^{-} \\
& \cdot \mathrm{O}_{2}^{-}+\mathrm{H}^{+} \rightarrow \cdot \mathrm{HO}_{2} \\
& \mathrm{e}^{-}+\cdot \mathrm{HO}_{2}+\mathrm{H}^{+} \rightarrow \mathrm{H}_{2} \mathrm{O}_{2} \\
& \mathrm{e}^{-}+\mathrm{H}_{2} \mathrm{O}_{2} \rightarrow \cdot \mathrm{OH}+\mathrm{OH}^{-}
\end{aligned}
$$


Consequently, the generated $\bullet \mathrm{O}_{2}{ }^{-}$and $\bullet \mathrm{OH}$ acting as effective oxidants will react with the MB molecules, producing $\mathrm{CO}_{2}$ and $\mathrm{H}_{2} \mathrm{O}$ as final products. However, since the standard redox potential $E^{0}\left(\cdot \mathrm{OH} / \mathrm{OH}^{-}, 1.99 \mathrm{~V}\right)[43]$ is more positive than the VB position of $\mathrm{g}-\mathrm{C}_{3} \mathrm{~N}_{4}(1.65 \mathrm{~V})$, the photoinduced holes in the VB of $\mathrm{g}-\mathrm{C}_{3} \mathrm{~N}_{4}$ cannot oxidize $\mathrm{OH}^{-}$or $\mathrm{H}_{2} \mathrm{O}$ to form $\bullet \mathrm{OH}$. This suggests that the photogenerated hole is not a main effective species for the MB degradation in this study. Based on the above observations and discussion, the possible MB degradation mechanism is ascribed mainly to the generation of active species induced by the photogenerated electrons. More detailed studies to fully understand the mechanism are presently being conducted.

\section{[Fig. 9, single column fitting image]}

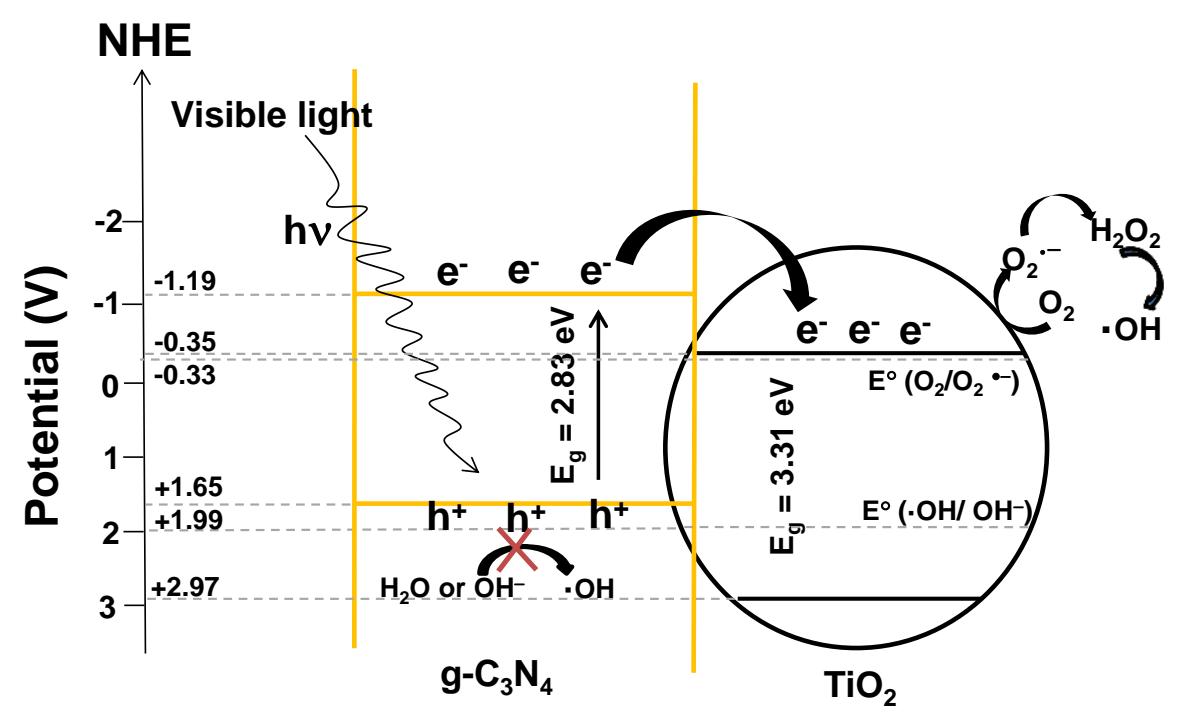


Fig. 9. Proposed mechanism for the photoexcited electron-hole separation and transport processes at the $\mathrm{g}-\mathrm{C}_{3} \mathrm{~N}_{4} / \mathrm{TiO}_{2}$ interface under visible light irradiation.

\section{Conclusions}

The $\mathrm{g}-\mathrm{C}_{3} \mathrm{~N}_{4} / \mathrm{TiO}_{2}$ composite films with different $\mathrm{g}-\mathrm{C}_{3} \mathrm{~N}_{4}$ weight percentages have successfully been prepared by direct heating of melamine in the presence of preformed $\mathrm{TiO}_{2}$ nanoparticles. The improved MB degradation activity under visible light irradiation was observed from all g$\mathrm{C}_{3} \mathrm{~N}_{4} / \mathrm{TiO}_{2}$ photocatalyst films with the $50 \mathrm{wt} \% \mathrm{~g}-\mathrm{C}_{3} \mathrm{~N}_{4} / \mathrm{TiO}_{2}$ showing the best photocatalytic activity. Significantly, the photocatalytic performance of $50 \mathrm{wt} \% \mathrm{~g}-\mathrm{C}_{3} \mathrm{~N}_{4} / \mathrm{TiO}_{2}$ increased almost twice in comparison with pure $\mathrm{TiO}_{2}$. Such an enhanced photocatalysis is ascribed to the strong light absorption intensity and the red-shift of absorption range of the $\mathrm{g}-\mathrm{C}_{3} \mathrm{~N}_{4} / \mathrm{TiO}_{2}$ composites and possibly the improved electron-hole separation efficiency originated from the suitably matching conduction and valence band potentials between $\mathrm{g}-\mathrm{C}_{3} \mathrm{~N}_{4}$ and $\mathrm{TiO}_{2}$. Cyclic experiments also indicate the reusability and high stability of the obtained films. Based on the results obtained in this study, the possible photocatalytic mechanism of $\mathrm{g}-\mathrm{C}_{3} \mathrm{~N}_{4} / \mathrm{TiO}_{2}$ heterojunction catalyst under visible light irradiation is proposed.

\section{Acknowledgements}

This research was supported by Thailand's Office of the Higher Education Commission, Uttaradit Rajabhat University; The institute for the Promotion of Teaching Science and Technology (IPST); Graduated school, Chiang Mai University; the National Research University Project under Thailand's Office of the Higher Education Commission, Materials Science Research Center; the Thailand Research Fund (TRF) and the Commission on Higher Education (CHE) Grant 
(MRG5580134). The assistance from Jianjian Lin of ISEM and Dr. Tony Romeno of Electron Microscopy Center and ANFF, University of Wollongong for BET SSA and SEM are also acknowledged. In addition, Dr. Chen would like to thank UoW International Linkage Grant to support this international student exchange program.

\section{References}

[1] M. Faisal, S.B. Khan, M. Rahman, A. Jamal, M.M. Abdullah, Appl. Surf. Sci. 258 (2012) 7515.

[2] F. Liu, X. Shao, J. Wang, S. Yang, H. Li, X. Meng, X. Liu, M. Wang, J. Alloys. Compd. 551 (2013) 327.

[3] M. Shahid, I. Shakir, S.J. Yang, D.J. Kang, Mater. Chem. Phys. 124 (2010) 619.

[4] K. Sayama, H. Hayashi, T. Arai, M. Yanagida, T. Gunji, H. Sugihara, Appl. Catal. B: Environ. 94 (2010) 150.

[5] A.A. Vega, G.E. Imoberdorf, M. Mohseni, Appl. Catal. A: Gen. 405 (2011) 120.

[6] D. Dvoranova, V. Brezova, M. Mazur, M.A. Malati, Appl. Catal. B: Environ. 37 (2002) 91.

[7] A. Gora, B. Toepfer, V. Puddu, G. L. Puma, Appl. Catal. B: Environ. 65 (2006) 1.

[8] S. Hu, F. Li, Z. Fan, J. Hazard. Mater. 196 (2011) 248.

[9] R.L. Narayana, M. Matheswaran, A.A. Aziz, P. Saravanan, Desalination 269 (2011) 249.

[10] X. Pan, Y. Zhao, S. Liu, C.L. Korzeniewski, S. Wang, Z. Fan, Appl. Mater. Interfaces 4 (2012) 3944.

[11] F. Lin, D.M. Jiang, X.M. Ma, J. Alloys. Compd. 470 (2009) 375.

[12] J. Xu, Y.H. Ao, D.G. Fu, C.W. Yuan, Colloid. Surf. A 334 (2009) 107.

[13] S.Z. Chen, P.Y. Zhang, D.M. Zhuang, W.P. Zhu, Catal. Commun. 5 (2004) 677.

[14] F. Dong, W.R. Zhao, Z.B. Wu, Nanotechnology 19 (2008) 365607.

[15] R. Jaiswal, N. Patel, D.C. Kothari, A. Miotello, Appl. Catal. B: Environ. 126 (2012) 47.

[16] X. Cheng, X. Yu, Z. Xing, J. Wan, Energy Procedia. 16 (2012) 598.

[17] B. Chai, T. Peng, J. Mao, K. Li, L. Zan, Phys. Chem. Chem. Phys. 14 (2012) 16745.

[18] X. Chen, S. Shen, L. Guo, S.S. Mao, Chem. Rev. 110 (2010) 6503.

[19] X. Wang, X. Chen, A. Thomas, X. Fu, M. Antonietti, Adv. Mater. 21 (2009) 1609. 
[20] S.C. Yan, Z.S. Li, Z.G. Zou, Langmuir 25 (2009) 10397.

[21] Y. Wang, R. Shi, J. Lin, Y. Zhu, Energy Environ. Sci. 4 (2011) 2922.

[22] S.C. Yan, S.B. Lv, Z.S. Li, Z.G. Zou, Dalton Trans. 39 (2010) 1488.

[23] N. Boonprakob, N. Wetchakun, S. Phanichphant, J. Chen, B. Inceesungvorn, Adv. Mater. Res. 622-623 (2013) 883.

[24] N. Wetchakun, S. Phanichphant, Curr. Appl. Phys. 8 (2008) 343.

[25] A. Nattestad, M. Ferguson, R. Kerr, Y. B. Cheng, U. Bach, Nanotechnology 19 (2008) 295304.

[26] L. Ge, C. Han, J. Liu, Y. Li, Appl. Catal. A: Gen. 409 (2011) 215.

[27] X. Wang, K. Maeda, A. Thomas, K. Katanabe, G. Xin, J.M. Carlsson, K. Domen, M. Antonietti, Nat. Mater. 8 (2009) 76.

[28] L. Ge, C. Han, Appl. Catal. B: Environ. 117 (2012) 268.

[29] W. Liu, M. Wang, C. Xu, S. Chen, Chem. Eng. J. 209 (2012) 386.

[30] Y. Zhao, Z. Liu, W. Chu, L. Song, Z. Zhang, D. Yu, Y. Tian, S. Xie, L. Sun, Adv. Mater. 20 (2008) 1777.

[31] N.E. Mircescu, M. Oltean, V. Chis, N. Leopold, Vib. Spectrosc. 62 (2012) 165.

[32] H. Yan, H. Yang, J. Alloys. Compd. 509 (2011) L26.

[33] X. Zhou, F. Peng, H. Wang, H. yu, Y. Fang, Chem. Commun. 47 (2011) 10323.

[34] C. Miranda, H. Mansilla, J. Yánez, G. Colón, J. Photochem. Photobiol. A 253 (2013) 16.

[35] R.P. Vitiello, J.M. Macak, A. Ghicov, H. Tsuchiya, L.F.P. Dick, P. Schmuki, Electrochem. Commun. 8 (2006) 544.

[36] Y. Zhang, J. Liu, G. Wu, W. Chen, Nanoscale 4 (2012) 5300.

[37] K. Minsik, S. Hwang, J.-S. Yu, J. Mater. Chem. 17 (2007) 1656.

[38] G.-S. Shao, T.-Y. Ma, X.J. Zhang, T.Z. Ren, Z.Y. Yuan, J. Mater. Sci. 44 (2009) 6754.

[39] S. Ngamta, N. Boonprakob, N. Wetchakun, K. Ounnunkad, S. Phanichphant, B. Inceesungvorn, Mater. Lett. 105 (2013) 76.

[40] Y. He, J. Cai, T. Li, Y. Wu, Y. Yi, M. Luo, L. Zhao, Ind. Eng. Chem. Res. 51 (2012) 14729.

[41] M. Yang, Q. Huang, X. Jin, Mater. Sci. Eng. B 177 (2012) 600.

[42] Y. Xu, M.A.A. Schoonen, Am. Mineral. 85 (2000) 543.

[43] X.L. Fu, W.M. Tang, L. Ji, S.F. Chen, Chem. Eng. J. 180 (2012) 170. 


\section{List of Figure Captions}

Fig. 1. Thermogravimetric analysis of (A) pure $\mathrm{TiO}_{2}$, (B) $20 \mathrm{wt} \% \mathrm{~g}-\mathrm{C}_{3} \mathrm{~N}_{4} / \mathrm{TiO}_{2}$, (C) $50 \mathrm{wt} \% \mathrm{~g}$ $\mathrm{C}_{3} \mathrm{~N}_{4} / \mathrm{TiO}_{2}$, (D) $70 \mathrm{wt} \% \mathrm{~g}-\mathrm{C}_{3} \mathrm{~N}_{4} / \mathrm{TiO}_{2}$ and (E) pure g- $\mathrm{C}_{3} \mathrm{~N}_{4}$.

Fig. 2. XRD patterns of pure $\mathrm{TiO}_{2}$, pure $\mathrm{g}-\mathrm{C}_{3} \mathrm{~N}_{4}$ and g- $\mathrm{C}_{3} \mathrm{~N}_{4} / \mathrm{TiO}_{2}$ composites.

Fig. 3. FESEM images of (a) pure g- $\mathrm{C}_{3} \mathrm{~N}_{4}$, (b) pure $\mathrm{TiO}_{2}$ and (c) $50 \mathrm{wt} \% \mathrm{~g}-\mathrm{C}_{3} \mathrm{~N}_{4} / \mathrm{TiO}_{2}$ composite films and (d) the corresponding EDX spectrum of (c).

Fig. 4. TEM micrographs of (a) pure g- $\mathrm{C}_{3} \mathrm{~N}_{4}$, (b) pure $\mathrm{TiO}_{2}$ and (c,d) $50 \mathrm{wt} \% \mathrm{~g}-\mathrm{C}_{3} \mathrm{~N}_{4} / \mathrm{TiO}_{2}$ composite.

Fig. 5. FTIR spectra of pure g- $\mathrm{C}_{3} \mathrm{~N}_{4}$, pure $\mathrm{TiO}_{2}$ and g- $\mathrm{C}_{3} \mathrm{~N}_{4} / \mathrm{TiO}_{2}$ composites.

Fig. 6. (a) Survey scan of $\mathrm{TiO}_{2}$ and $50 \mathrm{wt} \% \mathrm{~g}-\mathrm{C}_{3} \mathrm{~N}_{4} / \mathrm{TiO}_{2}$ composite and high-resolution spectra for: (b) $\mathrm{C} 1 \mathrm{~s}$ and (c) $\mathrm{N} 1 \mathrm{~s}$ of $50 \mathrm{wt} \% \mathrm{~g}-\mathrm{C}_{3} \mathrm{~N}_{4} / \mathrm{TiO}_{2}$; (d) $\mathrm{Ti} 2 \mathrm{p}$ and (e) $\mathrm{O} 1 \mathrm{~s}$ of $50 \mathrm{wt} \% \mathrm{~g}-\mathrm{C}_{3} \mathrm{~N}_{4} / \mathrm{TiO}_{2}$ in comparison with those of $\mathrm{TiO}_{2}$.

Fig. 7. (a) Photocatalyst films and (b) UV-vis absorption spectra of (A) pure $\mathrm{TiO}_{2}$, (B) $20 \mathrm{wt} \%$ $\mathrm{g}-\mathrm{C}_{3} \mathrm{~N}_{4} / \mathrm{TiO}_{2}$, (C) $50 \mathrm{wt} \% \mathrm{~g}-\mathrm{C}_{3} \mathrm{~N}_{4} / \mathrm{TiO}_{2}$, (D) $70 \mathrm{wt} \% \mathrm{~g}-\mathrm{C}_{3} \mathrm{~N}_{4} / \mathrm{TiO}_{2}$ and (E) pure g- $\mathrm{C}_{3} \mathrm{~N}_{4}$ films. Inset is $(\alpha h v)^{1 / 2}$ and $(\alpha h v)^{2} v s$ photon energy $(h v)$ plot of pure $\mathrm{TiO}_{2}$ and $\mathrm{g}-\mathrm{C}_{3} \mathrm{~N}_{4}$ films, respectively.

Fig. 8. (a) $\mathrm{MB}$ photolysis and photocatalytic degradation over pure $\mathrm{TiO}_{2}$, pure g- $\mathrm{C}_{3} \mathrm{~N}_{4}$ and g$\mathrm{C}_{3} \mathrm{~N}_{4} / \mathrm{TiO}_{2}$ composite films and (b) cycling runs using $50 \mathrm{wt} \% \mathrm{~g}-\mathrm{C}_{3} \mathrm{~N}_{4} / \mathrm{TiO}_{2}$ film (the initial MB concentration of $10.0 \mathrm{mg} / \mathrm{L})$.

Fig. 9. Proposed mechanism for the photoexcited electron-hole separation and transport processes at the $\mathrm{g}-\mathrm{C}_{3} \mathrm{~N}_{4} / \mathrm{TiO}_{2}$ interface under visible light irradiation. 